\title{
Identity, Nationalism and the Response of Turkey to COVID-19 Pandemic
}

\author{
Enver Gülseven ${ }^{1}$ (D)
}

Received: 13 July 2020 / Accepted: 13 October 2020 / Published online: 27 November 2020

(c) Fudan University 2020

\begin{abstract}
This paper will scrutinize the response of Turkey to COVID-19 pandemic from an ontological security perspective to demonstrate how critical junctures may serve to the identity needs of its political elites. Highlighting the role of pandemic in the construction of political narratives, it aims to shed light on the potential implications of the crisis in shaping domestic power struggles as well as Turkish foreign policy choices. The analysis revealed that both ruling and opposition parties in Turkey are instrumentalizing nationalist narratives with an emphasis on protection and self-reliance, and are engaged in political opportunism during the outbreak. It also demonstrated how the pandemic facilitated the restoration of Turkey's ontological security in international arena while fostering nationalism and securing the "savior and protector" identity of its ruling elites. Nevertheless, the paper concludes that post-pandemic Turkish politics will be shaped by growing tension between religious and secular understandings of nationalism as well as frictions with allies and neighbors over the disputes in the Mediterranean and the Middle East. Thus, it can be suggested that enhanced ontological security of the country could be short lived.
\end{abstract}

Keywords Turkey · Turkish politics · Nationalism · Identity · Ontological security · COVID-19 pandemic

\section{Introduction}

The global COVID-19 pandemic and the measures taken by governments around the world constitute a major break to the normal state of affairs and a critical juncture that can speed up existing trends or transform societies for good and this includes Turkey too. The Eastern Mediterranean nation has recently been going through a new nationalist wave and a rise in anti-globalization sentiments in both its domestic

\section{Enver Gülseven}

envergulseven@gau.edu.tr; envergulseven@hotmail.com

1 Department of International Relations, Girne American University, University Drive, Karmi Campus, Via Mersin 10, 99428 Girne, Kıbris, Turkey 
and foreign policies. Although it is difficult to anticipate the precise impact of the ongoing pandemic due to uncertainty, the upsurge in nationalism is expected to be reinforced by the crisis. Like many other countries, Turkey was initially slow and relatively laidback in its response to the pandemic. Optimistic thinking and economic concerns prevented the government to implement draconian measures such as early lockdown and the country was quite confident in avoiding the pandemic even though it was surrounded by countries in Europe and the Middle East which reported thousands of cases. Indeed, Turkey's eastern neighbor Iran was one of the first countries in the world to witness a major outbreak outside China. Considering the importance of travel and tourism for Turkish economy, the government was hesitant to enforce restrictions on travel and international flights continued until February 23,2020 . Turkish television channels even publicized some pseudo-scientific claims that Turks are naturally immune to the coronavirus due to their genetic makeup and the outbreak could bypass Turkey. Nonetheless, COVID-19 was confirmed to have reached Turkey in early spring, with the first case being officially announced on March 11. In a relatively short time, the virus appeared to spread promptly and Turkey emerged as one of the severely affected countries by the pandemic overtaking China in terms of confirmed cases. The crisis and its potential effects represent a milestone for Turkish leadership, its ability to command political legitimacy and the country's foreign policy orientation.

The political legitimacy of the Justice \& Development Party (Adalet ve Kalkınma Partisi, AKP), which governs Turkey since 2002, does not rest solely on a steady economic growth in the last decades but also on an enhanced ontological security and reduced sources of national shame and anxiety in the Turkish society. During 2000s, Turkey experienced a rapid democratization process due to a series of reforms centered on freedom of expression and association, abolition of death penalty and elimination of army's political powers which fundamentally changed the political environment of the country (see Kubicek 2013). In line with these domestic changes, Ankara sought a greater role in regional and global system, aimed to integrate itself to several international institutions, began accession talks with the European Union (EU) and increased its visibility in global platforms. Turkey's membership in G20, its election as a non-permanent member of the United Nations (UN) Security Council in 2009, and its mediatory role in the Iranian nuclear deal are some of the examples of its activism in global affairs (Parlar Dal 2018). However, several external and internal developments in 2010s threatened the ontological security of both Turkey and its ruling elites. Despite pursuing a more active foreign policy and engagement in the Middle East, Africa and even Latin America, Ankara became increasingly insecure in its relationship with Western allies due to a long series of rifts over the past decade. At home, the government came to feel less secure as well due to the Gezi Park protests ${ }^{1}$ of 2013 , the intra-Islamist split between the AKP and

\footnotetext{
1 A wave of demonstrations and civil unrest which started as an environmental rally in Spring 2013 and stretched over the summer while turning into massive anti-government protests.
} 
the Gülen movement ${ }^{2}$ since 2013, the failed coup attempt of July 2016 and the currency crisis of 2018. The AKP responded by revising its self-image and highlighting the concept of "nation" and "Muslim" which were often used interchangeably. The party's narratives also fueled an increasingly anti-Western and nationalist populism at home while demonizing their domestic rivals for collaborating with foreign powers against Turkey's national interests (Ayan 2019). Following the coup attempt, AKP sponsored many national mega-projects while distributing economic benefits to consolidate its legitimacy. Nevertheless, deteriorating economic conditions, refugee crisis, and rising restrictions on individual freedoms, significantly challenged the governing party's popularity manifesting itself with a resounding defeat in 2019 local elections in which the party lost major cities to opposition candidates. ${ }^{3}$ COVID-19 pandemic hit the country in this polarized political climate and provided an opportunity for the AKP to consolidate its power and legitimacy against its rivals while securing its new religio-nationalist identity with an emphasis on self-reliance.

To illustrate this point, the present paper will analyze the response of the Turkish government to the pandemic from an ontological security perspective. Few recent studies have been published on the disrupting effects of COVID-19 to stable sense of collective identity and analyzed societal responses to ontological security challenges (see Sect. 2 immediately below). However, there is little discussion on unseen opportunities the crisis brings for political elites in restoring ontological security and strengthening legitimacy. This study aims to display constructive effects of critical junctures, like COVID-19, for political elites' identities especially in societies which suffer from pre-existing ontological insecurities like Turkey. Since societal need of ontological security is greater in times of extreme uncertainty, the pandemic presents opportunities for political elites to exploit through various strategies and narratives. Nationalism, in this regard, can provide a strong ideological apparatus for the elites and, therefore, has been a key variable shaping the responses of many states to COVID-19. In this context, this study investigates the role of pandemic in the construction of political narratives in Turkey as well as the potential impact of the crisis on Turkish domestic power struggles and foreign policy. It asks: How does nationalism shape the response of Turkish political elites to COVID-19? How does the pandemic facilitate the restoration of the ontological security of Turkey and its ruling elites through extensive use of nationalist narratives? Obviously, the drive for ontological security or nationalism cannot explain or cover every aspect of Turkey's response to the pandemic. Nevertheless, as suggested by Haas (1986: 709) "legitimate authority under conditions of mass politics is tied up to successful nationalism, when the national identity is in doubt, one prop supporting legitimacy is knocked away". Moreover, nationalism has continuously been in the forefront of political

\footnotetext{
${ }^{2}$ A transnational Islamic movement with political aspirations which is designated as a terrorist organization by Turkish government since 2016 coup attempt.

3 AKP lost control of most of the metropolitan municipalities to the opposition, including the capital, Ankara, the largest city, Istanbul, and other important cities such as Antalya, Adana and Mersin. The loss of Istanbul after the re-run of the election was considered a big blow to Erdoğan who began his political career as the city's mayor during 1990s.
} 
debates and processes in Turkey, is entrenched in its founding ideology, Kemalism, and is represented in almost all major political parties from the left to the extreme right in varying tones and degrees. It is deeply embedded in the shared subconscious of Turkish society and has strong connections with societal threat perceptions and anxieties. As such, nationalism provides Turkish elites with appropriate templates for justifications which are instrumental in mobilizing reactions to current issues of Turkey including the coronavirus crisis. Therefore, studying elite narratives in which the nation is reconstructed at critical junctures shed light on their role as mechanisms justifying certain policies while shaping societal perceptions of the meaning of the nation and state legitimacy. The paper proceeds in five sections. The next section reviews the literature on ontological security to provide a theoretical foundation for the study. It will clarify the concept and its contributions to understanding nationalism as well as the impact of critical junctures on political narratives and policies. The third section provides a historical background for the rise of nationalism in Turkish politics and subsequently demonstrates how events of the last decade undermined the ontological security of Turkey and its ruling elites while triggering a nationalist comeback in political narratives following a period of Europeanization. The next section illustrates the instrumentalization of the COVID-19 pandemic in restoring the country's ontological security in both domestic and foreign policies while safeguarding the legitimacy of its political elites by fostering nationalism. The conclusions of the research are drawn in the final section.

\section{Ontological Security and Critical Junctures}

The connection between ontological security and international relations has largely drawn on the works of British sociologist Anthony Giddens (1990) who defined the concept as "the confidence that most people have in their ongoing sense of identity, a sense that others are reliable and constant, and their material environments secure" (as cited in Dupuis 2012: 156). Giddens claims that ontological security is an essential psychological need for individuals in all societies and is an emotional, rather than a cognitive, phenomenon that is rooted in the unconscious (Giddens 1990:92). It is a feeling of security which is based on a confidence in the constancy of surroundings, the endurance of self-identity, the reliability of the routines of daily life, and the stable nature of habit. Ontological security develops from trust relationships established by early routines and interactions and is sustained when "home", which refers to a spatial context in which daily routines are performed and identities are constructed. Home provides a site of constancy in the social and material environment and is a secure base where people feel most in control of their lives since they feel free from external pressures (Dupuis and Thorns 1998: 28).

Ontological security has been applied to international relations by many scholars who argued that states seek to preserve not only their physical security but also the security of their self-conception even though the two can sometimes conflict with each other (see Kinnvall 2004; Mitzen 2006; Steele 2005). The degree to which this self-conception is endogenously or exogenously constructed is dependent on the given country's historical and current position within the international system. 
Self-conceptions of countries such as United Kingdom (UK) or United States (US) which played a hegemonic role in the construction of current international order, are more endogenously constructed while states that were "brought into" Western system of states tend to define themselves more in relation to the Western "other" (Akkoyunlu and Öktem 2016). Regardless of the type of construction, all states aim attaining consistent self-concepts that is constituted and maintained through a narrative which enables routinized foreign policy actions. From an ontological security view, narratives are understood as sense-making instruments that enable conceptions of stable selfhood to be proposed and secured across time and space (Malksoo 2015; Kinnvall 2004). For instance, nationalist narratives usually portray territories as "our" homes and a source of identification for "us" vis-à-vis the "other", who might be placed inside or outside the territory (Kadman 2015: 33). Similarly, narratives involving heroic leadership, national struggle, and sacrifice allow members of a society to simply attribute importance to certain events, and thus can be re-applied subsequently in different contexts. Besides narratives, states accomplish ontological security by routinizing relationships with significant others and eventually become attached to those relationships. In other words, attachment to routines is essential for an ontologically secure identity which enables capacity for rational action. Indeed, Mitzen (2006:345) defined ontological insecurity as an "incapacitating state of not knowing which dangers to confront and which to ignore" and argued that agents with ontological insecurity are more concerned with immediate needs. Consistently ignoring threats to ontological security generates "shame" for state agents which does not only threat their legitimacy but also may compel them to take "irrational" decisions which sacrifice their physical security.

Ontological security in contemporary globalized societies is more fragile and unstable due to the transformed nature of trust mechanisms which assists individuals to cope with the pressures of modernity and rapid changes. The globalization of economics, politics, and human affairs has made individuals and groups existentially more uncertain and ontologically less secure. In particular, cultural globalization dilutes national distinctiveness while weakening unique traditions and cultures around the world (Fergusan and Manbach 2012). Consequently, many societies fear losing a sense of distinctiveness which threatens the ontological security of their members. As Mitzen (2006: 352) noted society must be cognitively stable to secure the identities of individuals who will become attached to stable group identities and a key part of societal identity is its distinctiveness vis-a-vis other societies. Moreover, intensification of transnational links empowered sub-national groups with alternative self-conceptions which is generally perceived as a threat for national unity. Indeed, ontological security of states can be severely undermined by the political process of identity contestations and narrative-based disagreements that occur in national debates over self-identity (Steele 2005: 17). Hence, ontological insecurities are not only reflected towards other states and international system but also towards the society itself. Furthermore, financial globalization and interconnected nature of global economy made countries increasingly vulnerable to economic crises that precipitate critical junctures. Briefly, destabilizing effects of globalization trigger feelings of "homelessness" and alienation in many societies that enable their leaders to channel existential fears and feelings of loss and misery. 
Most studies on ontological security tended to underline the disrupting effects of critical junctures on state's routine behaviors. Giddens (1984: 61) defined critical situations as unpredictable self-identity threats which affect substantial numbers of individuals in a society and disturb the narratives and institutionalized routines of states. Ejdus (2017: 884) highlighted how states become ontologically insecure when critical situations rupture their routines and bring fundamental questions to public discourse. Accordingly, individual and collective agents exploit critical situations to challenge or back the legitimacy of ruling elites. In response, regimes must construct new narratives to consolidate social cohesion and demonstrate that they are capable of changing or preventing these critical situations so that they no longer endanger their identity (Steele 2005). Therefore, critical junctures are not only having disruptive effects but are also bringing new opportunities for political elites to secure their identities through narratives displaying their competence in handling the crisis. The COVID-19 pandemic is the latest among a long list of crises that have hit the world in the current age of globalization and provides a critical juncture that undermines the notion of international interdependence, the prominence of neoliberal economic model and thus ontological security of many globalized societies. It has posed exceptional challenges to our sense of self, identity, daily activities and institutionalized routines which enable individuals and societies to be ontologically secure. The outbreak triggered deep anxieties for many people in affected societies by swiftly rupturing their daily routines, trust relations and liberties which were taken for granted in an unprecedented way.

As stated in the introduction, few researchers have recently addressed the issue of the possible effects of the pandemic on ontological security of societies. Goode et al. (2020) examined societal responses to the perceived threats to ontological security in the US, UK, China and Russia and displayed how anxieties, conspiracy theories and everyday actions become conflated with nationalist tropes about unity and sovereignty during the pandemic. Mamzer (2020) also emphasized how COVID-19 and restrictions to prevent its spread, disrupted the sense of ontological security and prompted some irrational behaviors such as panic buying whereas Kirke (2020) argued that threats to ontological security has not led to a vacuum of meaning due to political myths constructed by media in the UK which suggest British society as united against the virus. Despite this interest, no one to the best of our knowledge, has provided a systematic analysis of political elites' strategies and narratives amid the pandemic from an ontological security perspective. This paper is a preliminary attempt to highlight opportunities brought by the COVID-19 pandemic for Turkish political elites in responding to ontological security challenges and securing identities through narratives displaying their competence in crisis management. Indeed, the handling of the pandemic can become a source of national pride or in contrast may put a country to shame and this makes COVID-19 crisis a severe test for the legitimacy of governments around the world. Hence, political elites need new narratives which represent and suggest societies as united against coronavirus pandemic to stick people together and re-establish ontological security by assuring that the situation is under their control. Such narratives play an important role in boosting societal morale, reinforcing collective ties and trust levels which are essential for being ontologically secure in such challenging times (Kirke 2020). During the pandemic, 
the risks of overdependence on global supply chains have fully entered the public consciousness and new narratives championed the concepts of self-reliance, renationalization of production and nationalism. Such concepts were utilized by political elites to provide a secure base through which members of a society may accomplish a sense of social cohesion and ontological security. Put differently, nationalism can be thought as a response to the contemporary problem of ontological insecurity in globalized societies especially during critical junctures like COVID-19 which threatens ruling elites' legitimacy. As Kinnvall (2004: 742) pointed out nationalism becomes an exceptionally strong response in times of swift changes and uncertain futures when combined with religion, and thus is more likely than other alternative identities to arise during crises of ontological insecurity. In many Muslim-majority societies, contemporary nationalism is often blended with narratives emphasizing religious elements. Despite its official secularism, Turkish elites are also applying an amalgamation of religious and nationalist narratives in recent decades as a remedy for internal and external ontological insecurities. At this point, let us now focus on the sources of Turkey's ontological insecurity which will help to understand how Turkish nationalism developed and why it is a key variable shaping the response of Turkish elites to the pandemic.

\section{Turkey's Ontological Insecurities and Nationalist Comeback}

Essentially, Turkey has a deep-rooted ontological insecurity which was shaped by its geopolitical and cultural in-betweenness on one hand and its partial success in modernization since the nineteenth century on the other (Çapan and Zarakol 2019). Even Huntington (1996) classified Turks as a torn society and an artificial bridge connecting two solid entities but is part of neither. Indeed, Turkey's last century has been shaped by debates on identity and modernization which dates back to late-Ottoman period. Prior to the Republic, Turkish nationalism was shaped in the milieu of the nineteenth century "late-comer" nationalisms as a reaction to nationalistic movements in the Balkans. As Keyder (2005: 3) states, "Turkish nationalism learned from, reacted against and was constrained by competing nationalisms". In addition, it developed alongside Pan-Ottomanism and Pan-Islamism until the humiliating defeats in the Balkan Wars (1912-13) which obliged Ottoman intellectuals to search for the cultural, ethnic and linguistic roots of Turkish identity. Although Turkish national awakening was inspired by the ideas of French Revolution and Enlightenment, the German romantic concept of a homogeneous society linked by language, ethnicity and religion was the working principle of early Turkish nationalism (Canefe 2003: 135). It is indeed suggested that the contradiction of Turkish nationalism emanate from its endeavor to merge the missions of French and German models (Kadı̆̆ lu 1996).

Following the collapse of the Empire in 1922, Republican era witnessed the institutionalization of nationalist narratives which aimed to construct a distinct, proud and self-assured "Turk" along with a Westernization project as a response to ontological insecurities stemming from the Ottoman period. Nationalism was defined as one of the fundamental and unchanging principles of the Republic of Turkey which 
was established by Mustafa Kemal Atatürk in 1923. However, since then, there has never been a consensus over Turkey's national identity, either inside or outside the country. Westernization was a top-down social engineering project which raised societal resistance from the beginning. Likewise, the assimilationist nation-building process attempted to enforce a uniform identity and associated "Turkishness" with citizenship without taking ethnic or linguistic differences into account. Religion was excluded from the public sphere and replaced with secular nationalism as the basis of state legitimacy (Bozdağlıoğlu 2003). The emerging Turkish identity and nationalism also sought a fresh start uncontaminated by Islamic past or Ottoman cosmopolitanism which is described as "voluntary or institutionalized amnesia" (Keyder 2005: 9). Ziya Gökalp, one of the most influential ideologues of the Turkish Republic, emphasized Turkey's difference from the Ottomans and made clear that the nation of the future would not be Ottoman anymore, but Turkish (Gökalp 1923/1970). This discontinuity in the sense of "self" generated by early republican nation-building would later constitute an essential source of Turkey's ontological insecurity (Çapan and Zarakol 2019). Kemalist nationalist narratives also involved the dilemma of a choice between imitation of the West and construction of a distinct identity (Kadıoğlu 1996: 185).

A similar contradiction was reflected in foreign policy narratives too which adopted a rhetorical suspicion towards the West that was concurrently idealized as a civilization to join. Despite the Westernizing reforms, Turkey has always had an ambivalent relationship with the West which became an institutional ally during the Cold War. Although, the country integrated itself to many Western institutions after the Second World War (WW2), most notably North Atlantic Treaty Organization (NATO) and Council of Europe without much questioning of its cultural identity, it failed to routinize its relationship with the West which remained as the significant "other" of its self-conception. A siege mentality, "paranoia towards the outside world" 4 fear of disintegration and the persistent anxiety over Kurdish separatism remained strong in Turkish political mindset. In this context, nationalism which engendered a founding momentum for the Republic continued to be associated with narratives of defense. However, militant secularism was abandoned by postwar political elites of Turkey who perceived positivistic and materialistic types of nationalism as susceptible to the penetration of Communism (Çetinsaya 2007: 368). From 1960s onwards, Islam gradually regained its position in the public sphere and found its expression in nationalist narratives, education and foreign policy vision which aimed to avoid being branded as a puppet of the West (for a detailed discussion see Grigoriadis 2013; Aykan 1993). In spite of such efforts, Ankara somehow felt like an "outsider" both in the Middle East and the West.

Such feelings of exclusion were intensified with the rise of identity politics towards the end of Cold War when Turkish identity became a cornerstone of

\footnotetext{
4 This collective fear of disintegration is known as the "Sèvres syndrome", named after the treaty that led to the partition of the Ottoman Empire after WW1 between the Greece, Britain, France, Italy as well as Kurds and Armenians. Although the treaty was never implemented due to the success of Turkish War of Independence, it remains an important source of isolationist sentiments in Turkish foreign policy.
} 
political debates inside and outside the country. Following the coup in 1980, the role of religion in Turkey's national identity was reinforced with the ideology of "Turkish-Islamic synthesis" 5 which highlighted the glorious periods of Ottoman history and asked Turks to feel proud of their Ottoman-Islamic heritage. Nevertheless, this attempt opened up the Kemalist pandora's box out of which have emerged multiple identities and proved too little too late to enhance Turkey's ontological security. In early 1990s, religious and ethnic variants of Turkish nationalism reappeared and influenced Turkish political scene in the face of Islamic revivalism and Kurdish separatism. As Poulton (1997: 322) observed "a number of nationalisms vie for hegemony over possession of the whole or parts of population in Turkey". After the disappearance of Soviet ideological threat, Turkey's identity and the international role attached to it were also threatened with the shifting determinants of Western identity and growing importance of religion and culture as identity markers. Cold war perceptions of Turkey as European or Western were downgraded while its Islamic identity was returning to world-wide prominence. In response, Ankara attempted to reconcile its interests with Western preferences during early 1990s and prioritized its strategic commitment to the West and its ontological security over economic interests and physical security. ${ }^{6}$ This period also witnessed a greater integration of the country into global economy and culture which challenged simple definitions of identity while widening the socio-economic gap between the "winners" and "losers" of globalization. In parallel with the rise of political Islam in a global context, mechanisms of economic globalization and the associated process of neo-liberal restructuring accelerated the rise of Islamist parties to a position of prominence in Turkish politics (Öniş 1997). Indeed, the Welfare Party (Refah Partisi, RP) succeeded in mobilizing alienated masses by fusing religious and nationalist narratives, advocating economic independence and opposing Western values, especially secularism. When the RP, with its religio-nationalist ideology, ${ }^{7}$ came to power in 1995 and attempted to challenge Turkey's Western orientation in both domestic and foreign policies, it was contested and banned by the army and the constitutional court.

Following a decade of political turmoil and economic instability in 1990s, AKP was widely seen as a solution to Turkey's ontological insecurity both at home and within the international system (Çapan and Zarakol 2019). The anti-status quo party was established by members of banned Islamist parties including Recep Tayyip Erdoğan, yet adopted a very different approach from its predecessors by distancing itself from religious nationalism. Indeed, the AKP allied itself with liberal circles and pursued a harsh position against the nationalist opposition arising from

\footnotetext{
5 Following the 1980 coup, leftist parties were outlawed in Turkey which enabled Islamist movements to mobilize marginalized communities. The "Turkish-Islamic synthesis" was also promoted by the army to consolidate national identity and integrity in the wake of rising separatist tendencies among the country's Kurdish population.

${ }^{6}$ For instance, President Özal supported the US during the First Gulf War despite the economic sanctions which were themselves costly for Turkey. Moreover, the country faced a major migration crisis by receiving thousands of refugees from neighboring Iraq which enhanced the politicization of Kurdish identity while rising terrorism and security concerns.

7 This ideology is officially called Milli Görüş which is generally translated as "National Outlook".
} 
the right as well as the left. Meanwhile, AKP government managed to pass many democratizing reforms while embracing a pro-EU approach and is even named by some as a "Muslim Democrat" or "Post-Islamist" entity (Zucconi 2003). Despite suspicions among the secularist circles, AKP achieved getting the support of liberals, Kurds and top business groups which paved the way for the establishment of a new and powerful pro-EU bloc cutting across the secular-Islamist divide in Turkey. The party was believed to merge democracy and Islam, neo-liberalism and conservatism while embracing a bridge role for Turkey between civilizations. Through EU-related reform process, the AKP was presumed to bring the army under civilian control, softened the Kurdish issue, adopted a conciliatory approach in relations with neighboring countries and pioneered Turkey's accession to the EU. ${ }^{8}$ Turkey was also imagined to emerge as an economic powerhouse and a middle power, ultimately gaining the respect of the international community especially from the West. All these developments were built through a societal consensus around EU ambitions and eventually undermined the main sources of Turkey's ontological insecurity. Indeed, Turkey has been portrayed as a role model for other Muslim-majority states with its rapid economic growth and democratizing reforms.

Eventually, the EU officially commenced membership talks with Turkey in October 2005. However, the euphoria would prove to be short lived for the country when some member states such as Austria and France have declared their intentions to hold referendums regarding Turkish accession. Moreover, the unresolved issue of Cyprus regardless of Ankara's conciliatory approach in 2004 Annan peace plan, ${ }^{9}$ remained as a major impediment for negotiations which have been stalled since 2006 due to a number of internal and external issues. Despite faded prospect of EU membership, European norms and standards continued to be used as a reference point in the narratives used by AKP leaders until 2013. Indeed, Turkey even attempted to justify its increasingly active, assertive and autonomous foreign policy in the Middle East with EU norms arguing that its engagement and mediation aim bringing peace and stability to the region. Nonetheless, domestic tension and rising isolation in the West deeply threatened the ontological security of Turkey's ruling elites who began using populist tactics to consolidate their legitimacy especially after the Gezi Park protests of 2013. Although the protests had begun as an environmental rally to save a small park in Central Istanbul, the events rapidly turned into a country-wide antigovernment movement and represented a challenge to AKP's hegemony in the face of widespread societal frustration. In response, the party's narratives represented the protestors as opponents of the "national will" while reproducing itself as the sole defender of the nation against internal and external foes (Bilgiç 2018: 259). Prime

\footnotetext{
${ }^{8}$ The swift transformation of Political Islamists in Turkey generated suspicions amongst the secularist actors in Turkey who were concerned about a "creeping Islamization" process through strategic use of EU reforms. While some claimed that this change is tactical, others emphasized a social learning process among Turkish Islamists due to past experiences and greater interaction with the West. For a detailed discussion see (Dağı 2005).

9 The UN plan suggested the establishment of a federal system in Cyprus between Turkish and Greek Communities of the island and was supported by the EU as well. Although the majority of Turkish Cypriots backed the plan in a referendum in 2004, it was rejected by most Greek Cypriots.
} 
Minister Erdoğan highlighted the concept of national will as a central pillar of his speeches at "Respect for the National Will" meetings across the country. The government also began adopting a confrontational position against EU members while querying if they have the appropriate moral standing to criticize the government's reaction to the protestors. The AKP leaders particularly instrumentalized democratic deficiencies and rise of populism in some European countries to deflect valid criticisms of Turkey (Çapan and Zarakol 2019: 275).

Following the disappointment in 2015 elections, ${ }^{10}$ nativist themes began dominating AKP narratives which emphasized the slogan Yerli ve Milli (Local and National) to promote the projects of the party. Nativist rhetoric was accompanied by a surge in populist narratives after the intensification of tension with Gülen movement and the coup attempt on July 15, 2016. Following the failure of the coup, Erdoğan blamed the movement for masterminding and implementing the attempt while initiating a widespread purge. Moreover, the AKP narratives declared the movement as a terrorist organization, condemned its growing links with the US and fueled anti-Western and nationalist populism at home. ${ }^{11}$ In the wake of the coup attempt, more "national will" meetings and rallies were organized by the government, while bridges and squares were being renamed with references to "national will" (Bilgiç 2018). Meanwhile, Erdoğan initiated his party's new alliance with ultra-nationalist groups who are ideologically closer to the Nationalist Movement Party (Milliyetçi Hareket Partisi, MHP). Skepticism towards the West facilitated this new electoral right-wing coalition between Turkish religious conservatives and nationalists. However, this was more than a strategic alliance for electoral purposes, and was actually a reflection of a solid ideological fusion. Indeed, the AKP and MHP have already established a noticeable symbolic language to blend traditional religious and nationalist history and narratives.

In addition to its alliance with nationalist groups, the AKP leadership also channeled the public's annoyance and confusion into a defensive national myth of "New Turkey" by placing the coup attempt and the public resistance at the center of the national consciousness. Indeed, the concept of "New Turkey" existed in AKP's political lexicon since the party lost its reformist momentum in early 2010s and has been used by its leadership in reference to Turkey being a regional power and an advanced democracy free of the military's tutelage (Taş 2020). After the failed coup attempt, New Turkey concept was highlighted by representing Erdoğan as a saviorleader of an "independence war" which the nation had been waiting for. By doing so, the party has merged the deep sense of victimhood among religious conservatives

\footnotetext{
${ }^{10}$ In 2015 elections, the AKP lost its parliamentary majority for the first time in 13 years and failed to establish a coalition which resulted in a snap general election in which the ruling party regained majority.

11 Indeed, ideological convergence between AKP and the Gülen movement due to their moderate understanding of Islam and emphasis on Turkey's Ottoman past enabled their cooperation in 2000s against the military tutelage. However, this alliance came to an end when Gülenist prosecutors launched a highprofile corruption investigation against top officials of the AKP and members of Erdoğan family. Dissociation was also linked with the erosion of Kemalists' ideological hegemony in the post-2010 period, which removed common threat perceptions and prompted a mutual need for the re-construction of "self" and "other" conceptions (See Ayan 2019).
} 
with the anti-Western and isolationist approach of Turkish nationalists. Subsequently, the government was further granted extensive emergency powers by the Parliament which allowed the AKP to rule by decree, weaken political rivals, and implement far-reaching constitutional changes which transformed the parliamentary system of Turkey into an executive presidency. Despite significant enhancement of his powers, Erdoğan and the AKP still feel the need for fundamental democratic justification which is threatened recently by many factors including Syrian refugee crisis and the currency and debt crisis of 2018. Although Erdoğan blamed "foreign powers" for stormy fluctuations in the value of Turkish Lira and refused a bailout from the International Monetary Fund, AKP suffered humiliating defeats in 2019 local elections, losing control of Ankara and Istanbul for the first time in 15 years. Moreover, defectors from the party established new parties to contest Erdoğan's hegemony in Turkish politics. As the AKP moves towards a reinforced ontological insecurity while voters' faith in the party is declining, the government perceived the COVID-19 pandemic as an opportunity to restore its "savior" self-image and is capitalizing on it as a new means to promote popular support against its opponents.

\section{Turkey's Response to COVID-19 Pandemic and Efforts to Restore its Ontological Security}

As reported above, Turkish leadership was already dealing with plenty of domestic troubles even before the outbreak. Moreover, Ankara was increasingly insecure in its relationship with Western allies due to growing tension with the US and EU over economic and security concerns in the Middle East and Eastern Mediterranean. Concerned about its rising ontological insecurities, the AKP was already pumping religio-nationalist narratives and policies in the country in an attempt to strengthen its own identity and legitimacy. The wave of nationalism that seized Turkey in recent years brought many national projects as well, ranging from the manufacturing of a national tank to a national employment program and most notably the design and mass production of a domestic car (Doğan 2019). Indeed, Erdoğan unveiled Turkey's first fully domestically manufactured car in December 2019 just before the beginning of COVID-19 outbreak in China. Then pandemic hit the country in March 2020 as noted earlier and came to be another critical juncture threatening the ontological security and legitimacy of its ruling elites. The crisis was indeed expected to intensify AKP's existing problems. The country was still under economic pressure due to the after-effects of the currency crisis as well as its chronic problems of high unemployment and inflation. Since economy has become a major vulnerability for the AKP, Erdoğan was fully aware that renewed economic turmoil could be a fatal blow to his rule. Moreover, the President's self-image and representation of his leadership as the only way to protect the country from enemies could be damaged in case of an unsuccessful handling of the crisis which will provide opposition groups with the opportunity to strengthen their positions.

Nonetheless, the absence of a global response to the pandemic and vulnerabilities of international organizations, which left the hardest hit countries alone, has also strengthened the government's nativist narratives that emphasize self-reliance. 
Although international institutions like the World Health Organization have guided states on how best to deal with COVID-19, it is national governments that are perceived as mainly responsible for handling the pandemic and protecting their citizens. In this context, the Turkish government resorted to nationalism once again which provided an important source of meaning and identity as well as the securest apparatus for enhancing legitimacy amid the crisis. As Goode et al. (2020: 13) suggest, nationalist narratives contrast friend and foe, enhance nationalist sentiment by invoking the notion of a nation under siege while justifying radical political actions in times of uncertainty. Accordingly, the Turkish authorities used a war rhetoric and claimed that coronavirus justified concerns about the need to protect the country from "foreign threats" which were accelerated by globalization. Like many other countries, that protection has been linked with the need for repatriation and a rush to "return home" even at the cost of speeding up its spread as if borders and territory could provide a certain immunity (Megret 2020). Turkey started repatriating its citizens first from China and subsequently from other countries which were hit early by the pandemic. Moreover, the government implemented thermal screenings at airports, closed land borders with its neighbors and suspended air travel with many countries including China, Iran, Italy, and South Korea. When the virus reached Turkey despite these measures, the government intensified the use of nationalist narratives which were calling on Turks to unite against the virus. The AKP's COVID19 slogans underlined a "national struggle against a global problem" while stressing the importance of strong leadership during the crisis.

The initial measures of the government to tackle the virus were limited to asking people to self-isolate and practice social distancing, closing all schools including universities as well as parks and picnic areas, suspending flights and forbidding public meetings and mass prayers. It is noteworthy that banning mass prayers was particularly controversial since the governing party was hesitating to resent its conservative voters. ${ }^{12}$ Apart from such relatively light measures, the government was actually against extreme measures such as a total lockdown considering its negative socio-economic effects. Erdoğan expressed his opposition to a stay at home order which would halt all economic activity and said "continuing production and exports is the country's top priority and that Turkey must keep its wheels turning" (Gökay 2020). Indeed, Erdogan's statements were reflecting the idea that the pandemic can be a good opportunity for Turkish industrialists and Turkey could replace China after its shutdown in the production of semi-finished products that many European companies rely on. Meanwhile, the government announced a 100 billion lira (US $\$ 14.5$ billion) incentive package on March 18 which included tax postponement and subsidies directed at domestic consumption. The package included measures such as reducing value added tax on several items while suspending national

\footnotetext{
12 Indeed, the government's influential Directorate of Religious Affairs' role during the pandemic has become a source of controversy especially in regard to the treatment of pilgrims returning from Saudi Arabia. Moreover, the government's insistence for keeping mosques open when libraries, museums and bars were already shut down, was also heavily criticized by the opposition. Turkey finally announced its decision to suspend communal Friday prayers only on March 16, 2020 later than many Islamic countries including Iran and Kuwait.
} 
insurance payments in many sectors for a period of 6 months (Turkey Rolls out Stimulus Package 2020).

By mid-March, the country's ubiquitous Health Minister Fahrettin Koca initiated a new practice to consolidate social cohesion and morale during a speech at the parliament when he asked lawmakers to clap health workers fighting against the virus (Y1ldirım and Tasdan 2020). Many Turks all around the country responded to this call and came outside their homes to cheer and honor doctors, nurses and other medical workers amid COVID-19. A hashtag \#BeraberBaşaracağ1z (\#wewillsucceedtogether) went viral on social media, with video clips displaying people clapping health workers accompanied by car horn and whistles. "Thank you for your third applause Turkey! Let's show our support to our health workers at every opportunity" Mr. Koca, wrote on social media while President Erdoğan and his wife were also applauding in Istanbul (Booth et al. 2020). Such new collective rituals and practices indeed contributed to the rise of nationalist sentiments in Turkey during the pandemic (for a detailed discussion on nationalism and COVID-19, see Woods et al. 2020). Meanwhile, the government also continued its infrastructure investments and even hold the first tender of its controversial mega-project of Kanal Istanbul ${ }^{13}$ in the midst of the outbreak which was harshly criticized by the city's opposition mayor who defined the tender as "mind boggling" whereas the government blamed him for political opportunism (Turkey Holds First Tender 2020).

Indeed, this was only the beginning of the rift between Erdoğan and the opposition mayors from secularist Republican People's Party (Cumhuriyet Halk Partisi, CHP), notably Ekrem İmamoğlu of Istanbul and Mansur Yavaş of Ankara, over the handling of the crisis. The opposition mayors competed with the government in societal measures to fight the virus by initiating fundraising campaigns, asking citizens to wear masks in public, as well as requesting a country-wide curfew. İmamoğlu organized food aid campaigns during this period in Istanbul which was harshly criticized by pro-government media (Kızıl 2020). Likewise, Ankara Metropolitan Municipality announced to provide financial aid and food package support for needy citizens, particularly those who lost their jobs due to the outbreak. The popularity of opposition mayors soared during the pandemic and represented a strong challenge to the government. Indeed, some polls conducted by private pollsters revealed that Mr. Yavas is perceived as more successful in managing the outbreak than the President (Metropoll Stratejik ve Sosyal Araştırmalar 2020a). Fearing an erosion in its distinctive self-conception as the "nation's protector", AKP leadership used narratives that demonized the opposition mayors to restore its ontological security. Erdoğan blamed the municipalities of attempting to establish a parallel state by introducing charity drives and added "non-state entities will not be permitted to run the affairs of the state,", demonstrating Turkey's extremely centralized structure since 2016 (Baydar 2020). The interior ministry has even compared actions taken by mayors to those of terrorist organizations and launched an investigation against their campaigns. The government also attempted to shut a field hospital built by the municipality of Adana

\footnotetext{
13 Kanal İstanbul is a mega-infrastructure plan described by Erdoğan as his "crazy project" when he first proposed it 2011 and refers to a $45 \mathrm{~km}$ shipping canal joining the Black Sea to the Marmara Sea.
} 
and prevented food distribution in neighboring Mersin. ${ }^{14}$ In late march, Erdoğan announced a national fundraising campaign named "We are self-sufficient Turkey" and donated 7 months of his salary to provide financial aid to citizens affected by the disease (Turkey Launches National Fundraising Campaign 2020). The campaign was indeed motivated by his rivalry with the opposition mayors and replaced donation accounts established by the municipalities of Ankara and Istanbul which were blocked by the government.

As the number of infections skyrocketed in late March, the Turkish authorities had to impose stricter measures. In early April, the government imposed a curfew for those under 20 or over 65 years old as well as anyone with chronic medical conditions yet age groups outside those brackets carried on working. Although, most small businesses in the service sector were closed while many companies in banking and finance sectors have switched to working from home, millions of workers in industrial sectors, especially metal, textile, mining and construction, continued to go to work due to fear of losing their jobs. The public transport system in Istanbul, where more than a quarter of Turkey's GDP is produced, continued serving over a million people daily by early April (Gökay 2020). The first intermittent 48-h curfew ${ }^{15}$ order was only announced on April 10 in 30 metropolitan municipalities and Zonguldak which led to panic buying and other incidents that were severely criticized by the opposition. ${ }^{16}$ Apologizing for the failure in crisis management, Interior Minister Süleyman Soylu declared his resignation the next day. Soylu's unexpected self-criticism was rare for the ruling party and was eventually rejected by Erdoğan (Turkish interior minister's rejected resignation 2020). However, it was revealing deep disagreements within the government concerning COVID-19 measures and displayed how critical junctures constrain the capacity of Turkish decision makers for rational action. Meanwhile, Turkey canceled celebrations of National Sovereignty and Children's Day scheduled for April 23 and asked people to sing the national anthem from their balconies. Additionally, state-appointed governorates in Istanbul ordered the cancellation of all events for the national day which would be organized by opposition-held municipalities. The Municipality of Kadıköy, a stronghold for Istanbul's secular middle-class, was also fined following a celebratory convoy in the borough. "No one will stop us from celebrating our national sovereignty," Kadıköy's mayor Dara Odabaşı replied (Turkey's ruling party wars with opposition 2020). Although celebrations were annulled due to the pandemic, the cancellation and AKP's general stance on national holidays associated with Atatürk sparked a new controversy. ${ }^{17}$ As Aron (2019: 1389) pointed out certain practices or rituals can

\footnotetext{
${ }^{14}$ Both cities are among the metropolitan municipalities that are controlled by the CHP since 2019 elections.

15 This practice of weekend curfews was unique to Turkey and were relaxed during the weekdays so people could continue working.

${ }^{16}$ Following the sudden announcement of the curfew, thousands of people rushed to supermarkets, bakeries and banks and ignored social distancing rules. Roads in big cities were packed with long lines outside grocery shops.

${ }^{17}$ Frequent cancellations or non-attendance of AKP leaders to national holidays associated with secularism and Atatürk in the past few years brought criticism regarding the party's stance on the Republic's
} 
become more salient for some members of the society but not others and this can generate a controversy over the essence of national identity. Under the conditions of quarantine, however, the need for ontological security that usual practices generate is greater. Therefore, both the government and the opposition attempted to disseminate a sense of normalcy in celebrating the national sovereignty day for bolstering solidarity and identity. Eventually, 2020 witnessed a different type of celebration for Turkey as millions of citizens marked the national days at their homes singing nationalist marches while waving flags in their balconies. This was indeed another clear manifestation of how nationalist impulses, either in its secular or religious versions, were reinforced amid the pandemic.

Taking advantage of this post-corona nationalist atmosphere, Erdoğan attempted to strengthen his country's ontological security by representing Turkey's performance in handling the pandemic as one of the world's most successful cases. The government highlighted Turkey's relatively low mortality rate, which stands at $2 \%$ and can be compared with Germany. Although Turkey's relatively young population partly explains lower fatality, Erdoğan also reminded the improvement of healthcare services under AKP in recent years while criticizing Western media for overlooking Turkey's success. ${ }^{18}$ In the meantime, the President inaugurated a massive hospital complex in Başakşehir, a conservative sub-urban district in Istanbul. In the opening ceremony, Erdoğan highlighted Turkey's power and self-sufficiency and said "Turkey, standing on its own two feet, is demonstrating its power at a time when international organizations are losing their meaning". On the other hand, Minister of Technology and Industry Mustafa Varank declared that Turkey will produce 5000 medical ventilators by the end of May and added "while the novel coronavirus pandemic has incapacitated many developed countries, Turkey is still standing tall" (Zontur and Ergöçün 2020). In late April, the Ministry of Foreign Affairs publicized that more than 40,000 Turkish citizens have been repatriated since the beginning of the outbreak. Commenting on the repatriation program Turkey's Communication Director Fahrettin Altun said "their trust in our healthcare system is a point of pride for us. President Erdoğan has pushed for continuous investments in our healthcare for years" (Aliyev 2020). He also stated that under the management of the President, none of the Turkish nationals will be "abandoned" anywhere around the world including those who desired to be in their homeland during the Muslim holy month of Ramadan. Such narratives with a focus on the concept of nationals with exclusive right to return "home" was indeed reconstructing the boundaries between Turkish citizens who should be protected at any cost and others while revealing the new face of Turkish nationalism revolving around pride for a relatively successful response to

Footnote 17 (continued)

founding principles. The government's ban on alcohol in official receptions while adding Quran recitation sessions has been another source of controversy in recent years.

18 Unlike Germany which received a great deal of international attention and appreciation, Turkey's low death rate was attacked in some Western media outlets who blamed the country for its alleged unreliable official figures. New York Times claimed that the Turkish government is implementing a propaganda campaign by controlling information about the outbreak and hiding a wider catastrophe (NY times 20.4.20). 
COVID-19. A particularly noteworthy case which was a further display of the Turkish government's public relations campaign during the pandemic was the evacuation of a Turkish citizen who tested positive for the virus but was denied treatment in Sweden. Concerned about the laid-back approach of Swedish authorities to COVID19, family members of Emrullah Gülüşken asked for help from Ankara on social media which ended up as a success story when the patient was swiftly brought to Turkey and recovered shortly.

In addition to domestic developments, the AKP government is also relying on the pandemic to score foreign policy points and restore its ontological security in international arena. Foreign policy is indeed tied to nationalism in times of health crisis by means of humanitarian aid to other countries through which the donor extends global influence (for a detailed discussion see, Goode et al. 2020; Woods et al. 2020). Since the beginning of the outbreak, Turkey sent critical medical supplies and aid to more than 50 countries including its NATO allies such as the UK, US, Spain and Italy as well as many others in the Balkans, Middle East and Africa. The so-called "corona diplomacy" initiative came at a time when Ankara's world-wide reputation is quite low. It was part of the narrative which targeted domestic audience by reinforcing the claim that Turkey handled the crisis better than many advanced countries. Simultaneously, it was intending to enhance the country's public image and prestige globally, thus reconstructing the "soft power" narrative advanced by the government. Medical aid boxes sent to NATO allies were marked with Turkish flags, Presidential seal and quotes from the thirteenth century poet Rumi "there is hope after despair and many suns after darkness" (Pitel 2020). Providing medical support to its neighbors reflect Turkey's focus on its region and helps restoring its image and soft power aspirations in the Balkans and the Middle East. On the other hand, the pandemic provides an excuse to eliminate a long-time annoyance in Ankara's relations with the US and other European allies and possibly bringing an end to its isolation within NATO. Turkey's aid to Italy and Spain was particularly important not only because they were among the worst hit in Europe but also the assistance allowed Ankara to show its gratitude to Rome and Madrid for deploying air defense systems to safeguard Turkish airspace against a potential raid from Syria. In addition, both countries have remained committed to Turkey's EU negotiations process. In a letter to Italian and Spanish Prime Ministers, Erdoğan wrote "Turkey showed that it was a true friend even when the EU voiced various obstacles for support" (EU rapporteur, Italy, Spain thank Turkey 2020). The aids were sent through a NATO emergency agency and have been appreciated by the alliance. Indeed, NATO Secretary General Jens Stoltenberg praised Turkey's donations and tweeted "NATO solidarity in action. Proud to see allies supporting each other" with a hashtag \#StrongerTogether. In response, Presidential Spokesman İbrahim Kalın tweeted "Turkey stands together with its allies in times of crisis and hardship. We hope our allies do the same" (Demircan 2020), implying greater expectations of support and solidarity from NATO in fight against terrorism and other security issues. Moreover, Ankara declared that it would delay the activation of the Russian S-400 missile systems due to problems resulting from the pandemic. Such developments on one hand, enhanced Turkey's ontological security by re-establishing the practice/routine of cooperation within NATO which remains the country's longest 
institutional link with the West. Indeed, NATO membership is currently the strongest source of its claim to be a Western state. On the other hand, COVID-19 solidarity also helped securing trans-Atlantic alliance's self-conception in a period when its raison d'être has become increasingly questioned. ${ }^{19}$ In brief, the pandemic surely has helped enhancing Turkey's place within NATO and its neighborhood. Nevertheless, deepening tensions in Eastern Mediterranean over valuable gas fields as well as apparent rift with some allies like France regarding civil wars in Libya and Syria continues to threaten Turkey's ontological security by fueling its deep-rooted siege mentality amid the coronavirus crisis.

By mid-May, Turkey registered a persistent recovery in fifth week since the first COVID-19 case and towards the end of the month, daily cases dropped below 1,000 triggering a gradual normalization process. The government lifted curfews, eased much of the restrictions on travel while restaurants, malls and gyms were re-opening by early June. However, the orders and the timeline of the normalization exposed ongoing frictions within the government especially between Erdoğan's economic priorities and the Health Minister's more cautious attitude. Moreover, the opposition leaders criticized the government for assisting other countries when Turkey itself is suffering from the shortage of medical equipment while describing the normalization process as too early. Some non-governmental organizations argued that human lives were being put at risk for the sake of economic concerns and particularly disapproved the opening of shopping malls. ${ }^{20}$ Surely, getting Turkey back to its normality remains as a challenge for the government and the normalization is bringing risks which are further complicated by growing political instability and economic problems. As of late June, the normalization brought the risk of a second wave as the country's number of daily cases jumped back to the highest in nearly a month. Meanwhile, Erdoğan attempted to change the political agenda in the country by reconverting Hagia Sophia ${ }^{21}$ museum into a working mosque after nearly 9 decades while warning other states not to interfere into the internal affairs of Turkey. ${ }^{22}$ Turkish President joined several senior ministers for the opening ceremony in which religious affairs agency president, Ali Erbaş, held up a sword in reference to Ottoman traditions while thousands of supporters were celebrating the event outside with Turkish flags (Hagia Sohpia: Former Istanbul Museum 2020). The populist move was indeed responding to societal demands especially from AKP's conservative support base as well as the party's nationalist allies. Furthermore, Erdoğan upholds

\footnotetext{
19 Only a few years back, Donald Trump declared the bloc as "obsolete" while Emmanuel Macron declared NATO as "brain dead" highlighting what he sees as fading commitment of member states.

20 The decision to keep parks and open-air facilities shut while allowing shopping malls to open was particularly criticized by the opposition, displayed inconsistencies of the normalization process and raised questions about the government's commitment to scientific guidance.

21 Hagia Sophia was constructed by Byzantines as a church and was converted into a mosque by Ottomans until it was finally converted into a museum by Atatürk in 1934.

22 The issue of re-converting the Hagia Sophia into a mosque has been discussed since the rise of identity politics in Turkey and is often instrumentalized by the Islamist and ultra-nationalist parties. The world-heritage site has always been given a symbolic meaning by both societal camps in Turkey. The conservative circles see it as a reminder of Ottoman imperial past whereas for secularists is stands as a symbol of secular nationalism and Kemalist cultural legacy.
} 
other fronts against the opposition by proposing to decentralize the country's bar associations and seeking to control social media platforms over tweets directed at his family. Such moves and the handling of the pandemic in general have clearly consolidated Erdoğan's hand whose approval rating increased from $41.1 \%$ during the early stages of the crisis to 52\% in June (Metropoll Stratejik ve Sosyal Araştırmalar 2020b). CHP's mayors in Turkey's biggest cities are also popular yet their efforts to organize local assistance during the crisis have been successfully blocked by the government. It can thus be suggested that the pandemic offers the government a convenient excuse for other domestic issues and the main opposition would have a hard time challenging the AKP in post-COVID-19 period.

\section{Conclusions}

This article has investigated the impact of COVID-19 pandemic on Turkish politics with a specific focus on the government's response from an ontological security perspective. It first addressed the relationship between ontological security and critical junctures in shaping political elites' narratives which enable certain types of domestic and foreign policies. Subsequently, the attention is paid to the origins of Turkish nationalism and sources of Turkey's ontological insecurities at home and vis-à-vis other countries from a historical perspective. It then demonstrated the identity transformation of Turkey's ruling AKP from a conservative democrat image towards a religio-nationalist one in an attempt to maintain its distinctiveness and ontological security. Lastly, the article illustrated the role of pandemic in shaping political narratives and domestic power struggles in Turkey and its effects on Turkish foreign policy towards its allies and other countries. As reported in the literature review, research on ontological security has tended to focus on the disrupting effects of critical junctures on state's routine behaviors while overlooking the possibility of how they can also serve the identity needs of societies. This study has gone some ways towards enhancing our understanding of unpredicted constructive effects of critical junctures for political elites' identity especially in societies which already suffer from ontological insecurities. In particular, leaders who faced a multitude of critical junctures in the past are better prepared to deal with challenges threatening ontological security and mitigate their disrupting effects. Such leaders can re-invent and utilize nationalist narratives linked with past crisis which reconstruct societal perceptions of national identity and state legitimacy. The findings of this study suggest that COVID-19 pandemic facilitated the restoration of Turkey's ontological security in international arena while fostering nationalism and securing the "savior and protector" identity of its ruling elites. Indeed, AKP has to rely on boosting Turkey's ontological security to maintain its legitimacy, and thus nationalism shapes the government's response to the crisis considering grim forecasts for economic recession. Since winning elections provides Erdoğan the legitimacy to claim the exclusive right to represent the national will, he attempts to maintain his popularity by instrumentalizing the pandemic and return to populist narratives and policies which depicted Turkey as being under attack from external and domestic foes. In this regard, the fight against COVID-19 is being portrayed as an independence war while 
the government's performance depicted as the envy of the world. At the same time, the "corona diplomacy" that Ankara has practiced during the outbreak is described by media close to the government as an indication of Turkey's global power status. Nevertheless, considering the likelihood of growing political instability and geopolitical tensions, it may be assumed that the restored ontological security of both Turkey and its ruling elites may not be long lasting. As illustrated above, mainstream opposition parties and actors are competing with the government in instrumentalizing nationalist narratives with an emphasis on protection and self-reliance and are also engaged in political opportunism. Hence, the pandemic is not only reinforcing nationalist tendencies in Turkey but also deepening the tension between religious and secular understandings of Turkish nationalism. Moreover, Erdoğan's "corona diplomacy" to advance Turkey's image and prestige through extensive use of soft power have certain limitations considering Ankara's deep problems with its neighbors and NATO allies which are expected to intensify in the post-pandemic period. Having said that, however, Turkish opposition remains extremely split and will compete against the AKP with its strong centralized leadership who will undoubtedly use all available resources of the state for being reelected in 2023 (Waldman 2020). With the opposition divided and state resources at his control, Erdoğan will likely remain in power, partly thanks to the pandemic which offers the incumbent party not only a securer identity but also an appropriate excuse for the troubling economy. Of course, predictions are difficult given the extreme uncertainty around the duration and intensity of the crisis. By the time of writing, coronavirus infections continue to rise in Turkey and across the globe, thus it is still too early to identify the precise impact of the pandemic on Turkish and international politics. The ultimate effects will apparently depend on whether the virus can be brought under control in the near future or whether its effects will be longer lasting, accompanied by further economic and geopolitical challenges.

\section{Compliance with Ethical Standards}

Conflict of interest The author states that there is no conflict of interest.

\section{References}

Akkoyunlu, K., and K. Öktem. 2016. Existential insecurity and the making of a weak authoritarian regime in Turkey. Southeast European and Black Sea Studies 16 (4): 505-527.

Aliyev, J. 2020. Turkey's response to coronavirus has been exemplary, Anadolu Agency, 24 April. https:// www.aa.com.tr/en/health/turkey-s-response-to-coronavirus-has-been-exemplary/1820204. Accessed 7 May 2020.

Aron, Hadas. 2019. Contesting the nation: Negotiating national narratives and the Jewish settlements. Nations and Nationalism 25 (4): 1386-1411.

Ayan, Arslan. 2019. An ontological reading of Turkey's AK Party-Gülen movement conflict. E-International Relations. https:/www.e-ir.info/2019/07/21/an-ontological-reading-of-turkeys-ak-party-gulen -movement-conflict/. Accessed 9 June 2020.

Aykan, M. 1993. The Palestinian Question in Turkish Foreign Policy from the 1950s to 1990s. International Journal of Middle East Studies 25 (1): 91-110. 
Baydar, Y. 2020. Covid19 hits Erdoğan's divisive domestic policies hard. The Arab Weekly, 5 April. https ://thearabweekly.com/covid-19-hits-erdogans-divisive-domestic-policies-hard, Accessed 28 Apr 2020.

Bilgiç, Ali. 2018. Reclaiming the national will: Resilience of Turkish authoritarian neoliberalism after Gezi. South European Society and Politics 23: 259-280.

Booth, W., K. Adam, and P. Ralfa. 2020. In fight against coronavirus, the world gives medical heroes a standing ovation. Washington Post, 26 March. https:/www.washingtonpost.com/world/europe/clapfor-carers/2020/03/26/3d05eb9c-6f66-11ea-a156-0048b62cdb51_story.html, Accessed 2 May 2020.

Bozdağlığlu, Y. 2003. Turkish Foreign Policy and Turkish Identity: A Constructivist Approach. New York: Routledge.

Canefe, N. 2003. Turkish nationalism and ethno-symbolic analysis: the rules of exception. Nations and Nationalism 8 (2): 133-155.

Çapan, Zeynep and Zarakol, Ayşe. 2019. Turkey's ambivalent self: ontological insecurity in 'Kemalism' vs 'Erdoğanism'. Cambridge Review of International Affairs 32 (3): 263-282.

Çetinsaya, G. 2007. Rethinking Nationalism and Islam: Roots of Turkish-Islamic Synthesis in Turkish Political Thought. The Muslim World 89 (3-4): 350-376.

Dağı, İhsan. 2005. Transformation of Islamic political identity in Turkey: Rethinking the West and westernization. Turkish Studies 6 (1): 21-37.

Demircan, D. 2020. Turkey stands with allies, hopes they do the same, 1 April. https://en.haberler.com/ turkey-stands-with-allies-hopes-they-do-the-same-1442490/. Accessed 2 May 2020.

Doğan, Z. 2019. Volkswagen factory deal could kick off Turkish national car project. Ahval News, July 30. https://ahvalnews.com/turkish-automotive-sector/volkswagen-factory-deal-could-kill-turkishnational-car-project. Accessed 26 May 2020.

Dupuis, Ann, and David Thorns. 1998. Home, home ownership and the search for ontological security. The Sociological Review 46 (1): 24-47. https://doi.org/10.1111/1467-954X.00088.

Dupuis, Ann. 2012. Ontological security. In International Encyclopaedia of Housing and Home, ed. Susan J. Smith, 156-161. Oxford: Elsevier Science.

Ejdus, Filip. 2017. Critical situations, fundamental questions and ontological insecurity in world politics. Journal of International Relations and Development. 21 (4): 883-908.

EU rapporteur, Italy, Spain thank Turkey for medical aid, solidarity. 2020. Daily Sabah, 2 April. https ://www.dailysabah.com/politics/eu-affairs/eu-rapporteur-italy-spain-thank-turkey-for-medical-aidsolidarity. Accessed 21 May 2020.

Ferguson, Yale, and Richard Mansbach. 2012. Globalization: The return of borders to a borderless world. New York: Routledge.

Giddens, Anthony. 1984. The Constitution of Society. Berkeley: University of California Press.

Giddens, Anthony. 1990. The consequences of modernity. Stanford: Stanford University Press.

Goode, J., D. Stroup, and E. Gaufman. 2020. Everyday Nationalism in Unsettled Times: In Search of Normality during Pandemic. Nationalities Papers. https://doi.org/10.1017/nps.2020.40 (forthcoming).

Gökalp, Z. 1970. Türkcülügün Esaslari (The Principles of Turkism), Istanbul: Varlık Yayınları. (Original work published 1923).

Gökay, B. 2020. Turkey tries to keep wheels of economy turning despite worsening coronavirus crisis. The Conversation, 2 April. https://theconversation.com/turkey-tries-to-keep-wheels-of-economyturning-despite-worsening-coronavirus-crisis-135370. Accessed 14 May 2020.

Grigoriadis, I. 2013. Instilling Religion in Greek and Turkish Nationalism: A Sacred Synthesis. New York: Palgrave Pivot.

Haas, E. 1986. What is nationalism and why should we study it. International Organization. 40 (3): 707-744.

Hagia Sohpia: Former Istanbul Museum welcomes Muslim worshippers. 2020. BBC News, 24 July. https ://www.bbc.com/news/world-europe-53506445. Accessed 20 Aug 2020.

Huntington, Samuel. 1996. Clash of Civilizations and the Re-Making of World Order. New York: Simon \& Schuster.

Kadığlu, A. 1996. The Paradox of Turkish Nationalism and the Construction of Official Identity. Middle Eastern Studies. 32 (2): 177-193.

Kadman, Noga. 2015. Erased from space and consciousness: Israel and the de-populated Palestinian villages of 1948. Indianapolis: Indiana University Press.

Keyder, Ç. 2005. A History and Geography of Turkish Nationalism. In Citizenship and Nation-State in Greece and Turkey, ed. Faruk Birtek and Thalia Dragonas, 3-18. New York: Routledge. 
Kinnvall, Catarina. 2004. Globalization and religious nationalism: Self, identity and the search for ontological security. Political Psychology 25 (5): 741-767.

Kirke, Xander. 2020. Anxiety and Covid-19: The role of ontological security and myth. E-International Relations. https://www.e-ir.info/2020/05/29/anxiety-and-covid-19-the-role-of-ontologica 1-security-and-myth/. Accessed 5 June 2020.

Kız1l, N. 2020. Polemics, controversies overshadow İmamoğlu's term as mayor of Turkey's largest city. Daily Sabah, 22 May. https:/www.dailysabah.com/politics/polemics-controversies-overs hadow-imamoglus-term-as-mayor-of-turkeys-largest-city/news. Accessed 3 May 2020.

Kubicek, Paul. 2013. Political conditionality and European Union's cultivation of democracy in Turkey. In Democracy promotion in EU's neighborhood: from leverage to governance, ed. Sandra Lavenex and Frank Schimmelfennig, 26-42. New York: Routledge.

Malksoo, Maria. 2015. Memory Must be Defended: Beyond the Politics of Menmonical Security. Security Dialogue. 46 (3): 1-17.

Mamzer, H. 2020. Postmodern society and COVID-19 Pandemic: old, new and scary. Society Register 4 (2): 7-18.

Megret, F. 2020. Covid-19 Symposium: Returning "home"-Nationalist international law in the time of Coronavirus. https://opiniojuris.org/2020/03/30/. Accessed 27 May 2020.

Metropoll Stratejik ve Sosyal Araştırmalar, 2020a. Türkiye'nin Nabzı (Turkey’s Pulse), April. https ://www.metropoll.com.tr/upload/content/files/1850-tnsubat20-icindekiler.pdf. Accessed 5 May 2020.

Metropoll Stratejik ve Sosyal Araştırmalar, 2020b. Türkiye'nin Nabzı (Turkey’s Pulse), June. https ://www.metropoll.com.tr/upload/content/files/1850-tnsubat20-icindekiler.pdf. Accessed 15 June 2020 .

Mitzen, Jeniffer. 2006. Ontological security in world politics: State identity \& the security dilemma. European Journal of International Relations 12 (3): 341-370.

Öniş, Ziya. 1997. The political economy of Islamic resurgence in Turkey: The rise of the Welfare Party in perspective. Third World Quarterly 18 (4): 743-766.

Parlar Dal, Emel. 2018. Profiling Middle Powers in Global Governance and the Turkish Case. In Middle powers in global governance. The rise of Turkey, ed. Emel Parlar Dal, 1-31. Cham: Palgrave Macmillan.

Pitel, L. 2020. What is behind Erdoğan's coronavirus diplomacy. Financial Times, 29 April. https://www. ft.com/content/8602c2da-f1d0-4a78-b848-4c8bf8b9e311. Accessed 21 May 2020.

Poulton, H. 1997. The Top Hat, Grey Wolf and the Crescent: Turkish Nationalism and the Turkish Republic. London: NYU Press.

Steele, Brent J. 2005. Ontological security and the power of self-identity: British neutrality and the American civil war. Review of International Studies 31 (3): 519-540.

Taş, H. 2020. The chronopolitics of national populism. Identities. https://doi.org/10.1080/10702 89X.2020.1735160.

Turkey holds first tender related to Istanbul canal project. 2020. Reuters, 26 March. https://www.reute rs.com/article/us-turkey-canal/turkey-holds-first-tender-related-to-istanbul-canal-project-idUSK BN21D1WY. Accessed 4 Apr 2020.

Turkey launches national fundraising campaign against Covid19. 2020. Daily Sabah, 30 March. https ://www.dailysabah.com/turkey/turkey-launches-national-fundraising-campaign-against-covid-19/ news. Accessed 1 June 2020.

Turkey rolls out stimulus package to protect economy, businesses from coronavirus fallout. 2020. Daily Sabah, 18 March. https://www.dailysabah.com/business/economy/turkey-rolls-out100bstimulus -package-to-protect-economy-businesses-from-coronavirus-fallout. Accessed 3 June 2020.

Turkey's ruling party wars with opposition municipalities during pandemic. 2020. Ahwal News, 19 April. https://ahvalnews.com/turkey-coronavirus/turkeys-ruling-party-wars-opposition-municipalitiesduring-pandemic. Accessed 5 May 2020.

Turkish interior minister's rejected resignation hints at deepened rifts. 2020. Arab News, 14 April. https:// www.arabnews.com/node/1658316/middle-east. Accessed 7 May 2020.

Waldman, S. 2020. How Covid-19 is handing Erdoğan a political lifeline in Turkey. World Politics Review, 28 May. https://www.worldpoliticsreview.com/articles/28796/the-turkey-economy-is-threa tened-by-covid-19-but-erdogan-isn-t. Accessed 3 July 2020.

Woods, E.T., R. Schertzer, L. Greenfeld, C. Hughes, and C. Miller-Idriss. 2020. COVID-19, nationalism, and the politics of crisis: A scholarly exchange. Nations and Nationalism. https://doi.org/10.1111/ nana. 12644. 
Yıldırım, O., and C. Tasdan. 2020. Turks applaud health workers fighting Covid19. Anadolu Agency, 19 March. https://www.aa.com.tr/en/health/turks-applaud-health-workers-fighting-covid-19/1772460. Accessed 4 May 2020.

Zontur, E., and G. Ergöçün. 2020. Turkish President opens giant hospital is Istanbul. Anadolu Agency. 20 April. https://www.aa.com.tr/en/health/turkish-president-opens-giant-city-hospital-in-istan bul/1811561. Accessed 27 Apr 2020.

Zucconi, Mario. 2003. Turkey's new politics and the European Union. Ethnobarometer Working Paper No. 7. Rome https://www.piemonteimmigrazione.it/PDF/ethnobarometer9.pdf. Accessed 19 May 2020.

Enver Gülseven is an Assistant Professor in the Department of International Relations at Girne American University where he teaches foreign policy analysis, European Union studies and Turkish foreign policy among other things. His research interests mainly lie in the area of identity politics, ontological security, Turkish politics, de-facto states and nationalism. 